\title{
Analisis Spasial Angka Morbiditas Jawa Tengah menurut Kabupaten/Kota Tahun 2017
}

Aprilia Lutviana Dewi

Politeknik Statistika STIS, 211709566@stis.ac.id

Aprillia Anis Saputri

Politeknik Statistika STIS

Emalia Septiani Hirma

Politeknik Statistika STIS

Fiqih Tri Mahendra

Politeknik Statistika STIS

Firza Refo Adi Pratama

Politeknik Statistika STIS

Rani Nooraeni

Politeknik Statistika STIS

ABSTRAK, Morbiditas merupakan salah satu indikator yang digunakan untuk mengukur derajat kesehatan penduduk. Penduduk di pulau Jawa memiliki derajat kesehatan lebih baik dibandingkan wilayah lain. Namun angka morbiditas di Jawa Tengah pada tiga tahun terakhir ini lebih tinggi daripada angka morbiditas Indonesia. Penelitian ini bertujuan untuk menganalisis angka morbiditas Provinsi Jawa Tengah secara spasial untuk menelusuri faktor-faktor yang mempengaruhi angka morbiditas Provinsi Jawa Tengah menurut kabupaten/kota secara spasial tahun 2017. Metode analisis yang digunakan adalah analisis deskriptif dengan peta tematik dan analisis autokorelasi spasial. Autokorelasi spasial diukur melalui indeks Moran. Sedangkan untuk analisis variabel-variabel secara spasial yang mempengaruhi angka morbiditas dilakukan dengan model SAR (Spatial Autoregressive Model) karena terdapat dependensi lag pada kabupaten/kota di Jawa Tengah. Dengan pemodelan SAR, didapatkan variabel prediktor yang signifikan memengaruhi variabel respon yaitu morbiditas pada $\alpha=$ $11 \%$ adalah variabel kemiskinan atau X3 dan variabel rasio fasilitas kesehatan per 30000 penduduk dengan nilai $\mathrm{R}^{2}=$ $46 \%$.

Kata Kunci: Morbiditas, Moran's Index, Spatial Autoregressive Model

\section{PENDAHULUAN}

Tujuan pembangunan berkelanjutan atau Sustainable Development Goals (SDGs) merupakan suatu rencana aksi global yang disepakati oleh para pemimpin dunia, termasuk Indonesia, guna mengakhiri kemiskinan, mengurangi kesenjangan dan melindungi lingkungan dengan 17 tujuan. Salah satu tujuan yang ingin dicapai dalam $S$ DGs adalah kesehatan yang baik dan kesejahteraan. Indikator kesehatan suatu daerah dapat ditinjau dari jumlah penduduk yang mengalami kesakitan atau terjangkit suatu penyakit (BPS, 2014). Angka kesakitan (morbiditas) yang didefinisikan sebagai keluhan kesehatan dalam Sirusa BPS merupakan gangguan terhadap kondisi fisik maupun jiwa, termasuk karena kecelakaan, atau hal lain yang menyebabkan terganggunya kegiatan sehari-hari. Angka morbiditas mempunyai peranan yang lebih penting dibandingkan dengan angka kematian (Kartasasmita, 2009 dalam Wulandari, K, Budiantara, I.N, Ratna, M., 2017). Hal ini disebabkan apabila angka kesakitan tinggi, maka akan memicu tingginya angka kematian. (Wulandari, K, Budiantara, I.N, Ratna, M., 2017).

Semakin tinggi morbiditas, menunjukkan derajat kesehatan penduduk semakin buruk. Sebaliknya semakin rendah morbiditas (kesakitan) menunjukkan derajat kesehatan yang semakin baik. Berdasarkan penelitian yang telah dilakukan oleh ahli kesehatan, morbiditas (kesakitan) disebabkan karena sakit sindrom gawat napas neonatus, tuberkulosis dan diare. Penyakit asma, tuberkulosis dan diare menimbulkan dampak negatif pada kehidupan 
pasien, menyebabkan anak sering tidak masuk sekolah, membatasi aktivitas pribadi maupun keluarga dan penurunan produktivitas kerja. Penyakit-penyakit tersebut muncul karena gaya hidup dan pola makan yang salah, serta lingkungan yang kotor semua bermula dari minimnya pengetahuan mengenai masalah kesehatan itu sendiri baik tentang gizi maupun lingkungan.

Berdasarkan, penjelasan tersebut mordibitas salah satunya bisa disebabkan oleh penyakit yang bersifat menular seperti tuberkolosis, demam berdarah, diare, dll. Kita tahu sendiri bahwa penyakit menular ada kaitannya dengan daerah yang berdekatan. Seperti hukum Geografi pertama yang di angkat Tobler "Semua hal berhubungan dengan hal lainnya, tetapi hal yang dekat lebih berhubungan dibandingkan dengan hal yang berjauhan".

Salah satu wilayah Indonesia yang kualitas kesehatannya baik adalah Pulau Jawa. Penduduk Pulau Jawa memiliki derajat kesehatan yang paling baik dibandingkan daerah-daerah lainnya (Arifianto, 2010). Dengan ini, angka morbiditas Pulau Jawa idealnya dapat dikatakan cenderung lebih rendah dibandingkan wilayah lainnya. Namun, terdapat hal yang menarik di mana Provinsi Jawa Tengah memiliki angka morbiditas lebih tinggi dari angka morbiditas Indonesia selama tiga tahun berturut-turut sejak tahun 2015 hingga 2017 yang ditunjukkan dalam Grafik 1 berikut :

Grafik 1. Tren Angka Morbiditas Indonesia dan Jawa Tengah

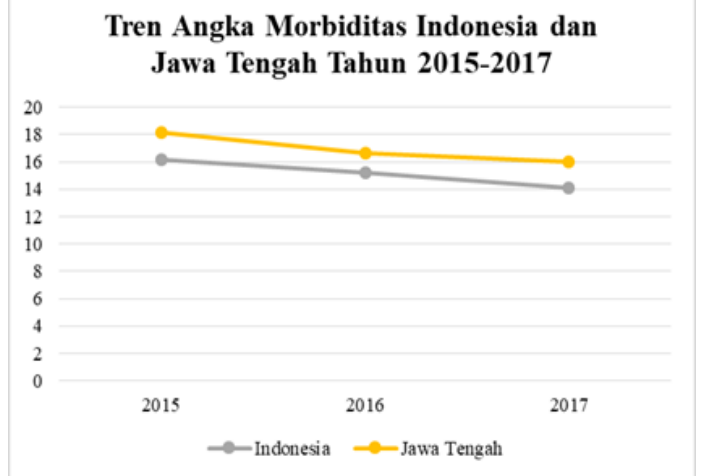

Apabila dilihat menggunakan peta spasial mordibiatas di Jawa Tengah, maka akan terlihat pengelompokan untuk kabupaten yang berdekatan.

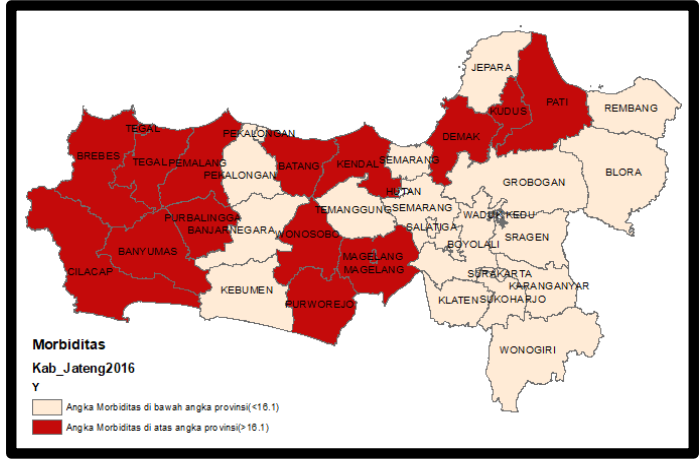

Sumber : Badan Pusat Statistik, publikasi. Gambar 1. Pola sebaran angka morbiditas antar kabupaten/kota di Jawa Tengah tahun 2017

Berdasarkan latar belakang diatas maka penelitian ini dilakukan untuk mengetahui efek spatial mordibitas di Provinsi Jawa Tengah, dengan analisis deskriptif menggunakan peta tematik dan analisis inferensia dengan menggunakan metode spatial lag.

\section{TINJAUAN PUSTAKA}

\section{REGRESI LINEAR BERGANDA}

Regresi linear berganda atau multivariate regression merupakan model regresi klasik sederhana dengan variabel prediktor lebih dari satu. Model yang terbentuk dari regresi ini adalah sebagai berikut:

$Y_{i}=\beta_{0 i}+\beta_{1 i} X_{1}+\cdots+\beta_{p i} X_{p}+\varepsilon_{i}$

di mana i merupakan jumlah variabel responden dengan skala pengukuran kontinu, $p$ merupakan jumlah variabel prediktor dengan skala pengukuran kualitatif dan kuantitatif, $\beta_{p i}$ merupakan parameter model regresi peubah ganda, $\varepsilon_{h}$ merupakan error yang diasumsikan $\varepsilon_{i} \sim \mathrm{N}\left(0, \sigma^{2}\right)$ dan $\operatorname{Cov}\left(\varepsilon_{i}, \varepsilon_{i *}\right)=0$ dengan $\mathrm{i} \neq \mathrm{i}^{*}$; $\mathrm{i}=1,2, \ldots, \mathrm{q} ; \mathrm{i}^{*}=1,2, \ldots, \mathrm{q}$.

Dengan diperolehnya model regresi yang terbentuk, ada asumsi klasik yang harus terpenuhi sebelum melakukan analisis spasial. Asumsi klasik yang harus terpenuhi adalah normalitas, multikolinearitas, dan heteroskedastisitas.

Model regresi klasik seperti di atas cenderung mudah dilakukan. Akan tetapi model tersebut memiliki asumsi bahwa setiap observasi harus independen. Apabila observasi tersebut memiliki efek spasial atau kewilayahan, model 
regresi klasik menjadi tidak efisien. Oleh sebab itu, diperlukan identifikasi efek spasial melalui regresi spasial.

\section{AUTOKORELASI SPASIAL}

Autokorelasi spasial merupakan nilai taksiran dari korelasi pada observasi yang memiliki efek spasial. Menurut Anelin (1993) dalam Saputeri (2019), bila nilai autokorelasi positif, maka artinya daerah yang berdekatan cenderung mengelompok. Autokorelasi spasial terbagi menjadi autokorelasi global dan lokal di mana keduanya dihitung dengan Global Moran's Index dan Local Moran's Index.

Autokorelasi global berfungsi untuk mengukur keterikatan wilayah secara umum di mana efek spasial akan dilihat dari besarnya nilai korelasi antar wilayah. Menurut Kosfeld (2006) dalam Wuryandanri, dkk (2014), perhitungan autokorelasi spasial dengan Global Moran's Index dapat dilakukan dengan dua cara, yaitu dengan matriks penimbang spasial tak terstandarisasi dan terstandarisasi. Dalam penelitian ini digunakan cara matriks penimbang spasial tak terstandarisasi yang rumusnya adalah sebagai berikut:

$I=\frac{N \sum_{i}^{N} \sum_{j}^{N} w_{i j}\left(Y_{i}-\bar{Y}\right)\left(Y_{i}-\bar{Y}\right)}{\sum_{i}^{n} \sum_{j}^{n} w_{i j}\left(Y_{i}-\bar{Y}\right)\left(Y_{i}-\bar{Y}\right)}$

Keterangan:

I : Indeks Moran secara global

$\mathrm{N}$ : banyaknya amatan

$\overline{\mathrm{Y}}$ : rata-rata pengamatan di seluruh wilayah

$\mathrm{Y}_{\mathrm{i}}$ : pengamatan di wilayah ke-i

$\mathrm{W}_{\mathrm{ij}}$ : penimbang tak terstandarisasi keterkaitan antara daerah $\mathrm{i}$ dan $\mathrm{j}$

Sementara itu, autokorelasi lokal berfungsi untuk mengukur dependensi spasial pada wilayah tertentu secara akurat. Semakin besar nilai Local Moran's Index, maka wilayah yang berdekatan cenderung mengelompok. Rumusnya adalah sebagai berikut:

$I_{i}=\frac{\left(Y_{i}-\bar{Y}\right)}{\sum_{i=1}^{N}\left(Y_{i}-\bar{Y}\right)} \sum_{j \neq i}^{N} w_{i j}\left(Y_{i}-\bar{Y}\right)$

Keterangan:

$\mathrm{I}_{\mathrm{i}}$ : Indeks Moran wilayah ke-i

Kedua indeks di atas memiliki rentang nilai -1 hingga 1 di mana ketika indeks bernilai positif artinya ada autokorelasi positif dan ketika indeks bernilai negatif artinya ada autokorelasi negatif. Sedangkan jika indeks bernilai 0 artinya tidak ada keterkaitan antar wilayah. Uji hipotesis yang dilakukan dalam indeks ini adalah sebagai berikut:

$\mathrm{H}_{0}: \mathrm{I}=0$ (tidak ada autokorelasi antar wilayah) $\mathrm{H}_{1}: \mathrm{I} \neq 0$ (ada autokorelasi antar wilayah)

Statistik uji:

$$
z(I)=\frac{I-E(I)}{\sqrt{\operatorname{Var}(I)}} \sim N(0,1)
$$

di mana nilai $\mathrm{E}(\mathrm{I})$ dan $\operatorname{Var}(\mathrm{I})$ adalah sebagai berikut:

$$
E(I)=-\frac{1}{n-1}
$$

$$
\operatorname{Var}(I)=\frac{n^{2} \sum_{i} \sum_{j \neq i} w_{i j}{ }^{2}+3\left(\sum_{i} \sum_{j \neq i} w_{i j}{ }^{2}\right)^{2}-n \sum_{i}\left(\sum_{j \neq i} w_{i j}\right)^{2}}{\left(n^{2}-1\right)\left(\sum_{i} \sum_{j \neq i} w_{i j}\right)^{2}}
$$

Keterangan:

n : jumlah amatan

E(I) : rata-rata Moran's Index

Var(I) : varians Moran's Index

Keputusan: Tolak $\mathrm{H}_{0}$ jika nilai $|\mathrm{z}(\mathrm{I})|>Z_{\frac{\alpha}{2}}$, artinya ada autokorelasi antar wilayah amatan.

\section{MODEL REGRESI SPASIAL}

Model regresi spasial merupakan pengembangan dari model regresi klasik yang dibentuk apabila terdapat dependensi atau efek spasial pada nilai observasi. Model ini terbentuk sesuati dengan kondisi data. Apabila terdapat dependensi spasial pada variabel respon antar wilayah, maka digunakan Spatial Autoregressive Model (SAR). Namun apabila terdapat dependensi spasial pada variabel respon dan prediktor, maka digunakan Spatial Durbin Model. Dan jika terdapat dependensi spasial pada variabel error, maka digunakan Spatial Error Model (SEM). Secara umum, model regresi spasial adalah sebagai berikut:

$\boldsymbol{y}=\rho W \boldsymbol{y}+X \beta+u$

di mana

$u=\lambda W u+\varepsilon \quad \varepsilon$

Keterangan:

y : vektor (berukuran $\mathrm{n} \times 1$ ) variabel respon pada pengamatan ke-i

$\rho \quad$ : koefisien spasial lag dari variabel respon

$\mathrm{W}$ : matriks (berukuran $\mathrm{n} \times \mathrm{n}$ ) penimbang spasial

$\mathrm{X}$ : matriks (berukuran $\mathrm{n} \quad \mathrm{x}$ ) variabel prediktor

$\beta$ : vektor (berukuran $\mathrm{p} \times 1$ 1) parameter koefisien regresi 
$\mathrm{u}$ : vektor (berukuran $\mathrm{n} \mathrm{x}$ 1) error yang diasumsikan mengandung autokorelasi

n : jumlah observasi

$\mathrm{p}$ : jumlah variabel

\section{PEMILIHAN MODEL REGRESI SPASIAL}

1. Lagrange Multiplier Test (LM Test)

Uji ini bertujuan untuk memilih model spasial yang sesuai.

$\mathrm{H}_{0} \quad: \rho=0$ (tidak ada autokorelasi spasial lag)

$\mathrm{H}_{1} \quad: \rho \neq 0$ (ada autokorelasi spasial lag)

Statistik uji:

$$
L M \rho=\frac{\left[\frac{e \prime W y}{\left(\frac{e l e}{N}\right)}\right]^{2}}{D+T} \sim X^{2}
$$

Keputusan: Tolak $\mathrm{H}_{0}$ jika nilai $|\mathrm{z}(\mathrm{I} \varepsilon)|>z_{\frac{\alpha}{2}}$, artinya ada autokorelasi antar wilayah amatan.

2. Robust Lagrange Multiplier Test (RLM Test) Uji Robust Lagrange Multiplier bertujuan untuk menentukan model spasial yang sesuai untuk melakukan analisis. Uji Robust Lagrange Multiplier digunakan ketika kedua uji LM untuk spasial Lag dan spasial error menunjukkan hasil yang signifikan, sehingga terdapat uji lanjutan untuk menentukan model mana yang lebih tepat.

\subsection{Uji Robust Lagrange Multiplier -Lag} Hipotesis RLM-Lag (Anselin,1999) : $\mathrm{H}_{0}: \rho=0$ (tidak ada dependensi spasial lag) $\mathrm{H}_{1}: \rho \neq 0$ (ada dependensi spasial lag)

Statistik uji :

$R L M \rho L M=\frac{\left[\frac{e^{\prime} \boldsymbol{w} y-e^{\prime} \boldsymbol{w e}}{\sigma^{2}}\right]}{D}$

Keputusan : tolak $\mathrm{H}_{0}$ jika nilai $R L M \rho>X^{2}{ }_{(1-}$ a)(1) atau $p$-value $<\alpha$ yang berarti terdapat autokorelasi lag pada data.

2.2 Uji Robust Lagrange Multiplier -Lag Hipotesis RLM-Error:

$\mathrm{H}_{0}: \lambda=0$ (tidak ada dependensi spasial error)

$\mathrm{H}_{1}: \lambda \neq 0$ (ada dependensi spasial error) Statistik uji :

$$
R L M \lambda \operatorname{LM} \lambda \frac{D+T\left[\frac{e^{\prime} W e}{\sigma^{2}}-\left(\frac{T}{D+T} \frac{e^{\prime} W y}{\sigma^{2}}\right]^{2}\right.}{\mathrm{DT}}
$$

Keputusan : tolak $\mathrm{H}_{0}$ jika nilai $R L M \lambda>X^{2}{ }_{(1-\alpha)(1)}$ atau $p$-value $<\alpha$ yang berarti terdapat autokorelasi error pada data.

\section{METODOLOGI}

\section{Variabel dan Sumber Data}

Penelitian ini menggunakan data sekunder yang berasal dari berbagai sumber

1. Angka morbiditas sebagai (Y), diperoleh dari Profil Kesehatan Provinsi Jawa Tengah 2017.

2. Persentase penduduk yang memiliki jaminan kesehatan $\left(\mathrm{X}_{1}\right)$, diperoleh dari Profil Kesehatan Provinsi Jawa Tengah 2017.

3. Persentase penduduk yang merokok tembakau selama sebulan terakhir $\left(\mathrm{X}_{2}\right)$, diperoleh dari Profil Kesehatan Provinsi Jawa Tengah 2017.

4. Persentase penduduk miskin $\left(\mathrm{X}_{3}\right)$, diperoleh dari website BPS.

5. Persentase penduduk yang memiliki sanitasi layak $\left(\mathrm{X}_{4}\right)$, diperoleh dari Profil Kesehatan Provinsi Jawa Tengah 2017.

6. Rasio fasilitas kesehatan setiap 30.000 penduduk $\left(\mathrm{X}_{5}\right)$, diperoleh dari Publikasi Jawa Tengah dalam Angka 2018.

\section{PEMBAHASAN}

\section{Analisis Deskriptif}

1. Persebaran Angka Morbiditas Antar Kabupaten/Kota di Provinsi Jawa Tengah

Tingkat kesehatan penduduk dapat dilihat dari banyaknya penduduk yang mengeluh kesakitan. Hal tersebut akan berpengauh terhadap aktivitas dan produktivitas manusia. Pentingnya masalah keluhan kesehatan untuk segera diatasi tercermin dari tujuan SDGs dan Nawa Cita. Berbagai upaya pemerintah dan masyarakat untuk mencapai tujuan tersebut dengan menurunkan angka morbiditas tersebut. 
Gambar 1 menunjukan persebaran angka morbiditas antar kabupaten/kota yang dibandingkan dengan angka morbiditas provinsi Jawa Tengah. Angka morbiditas tertinggi berada di Kabupaten Kudus (27,5\%) dan setengah dari kabupaten/kota di Jawa Tengah memiliki angka morbiditas di atas angka morbiditas provinsi yaitu $>16,1 \%$ yang berarti setengah wilayah dari provinsi Jawa Tengah memiliki masalah kesehatan yang perlu diatasi.

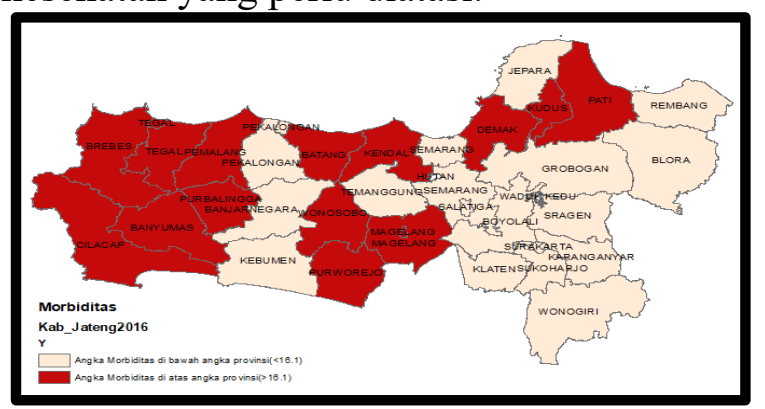

Sumber : Badan Pusat Statistik, publikasi.

Gambar 1. Pola sebaran angka morbiditas antar kabupaten/kota di Jawa Tengah tahun 2017

2. Persentase Penduduk yang Memiliki Jaminan Kesehatan Antar Kabupaten/Kota di Provinsi Jawa Tengah

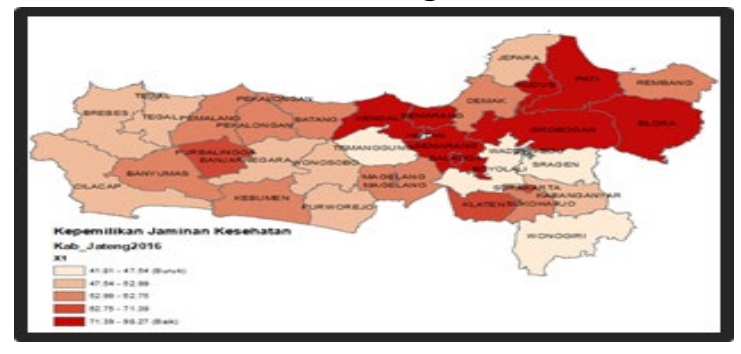

Sumber : Badan Pusat Statistik, publikasi.

Gambar 2. Pola sebaran persentase penduduk miskin di Jawa Tengah tahun 2017

Gambar 2 memvisualisasikan persentase kepemilikan jaminan pada masing-masing kabupaten/kota di Jawa Tengah pada tahun 2017. Pengelompokan kelas interval dilakukan dengan menggunakan natural breaks Jenk (meminumkan varians dalam kelas dan memaksimalkan varians antar kelas). Warna muda menunjukan kabupaten/kota dengan nilai persentase kepemilikan jaminan sosial 41,81\% $47,5 \%$. Sedangkan warna merah tua menunjukan kabupaten/kota dengan nilai persentase kepemilikan jaminan sosial 71,39\% - 98,27\%. Semakin gelap warna suatu kabupaten/kota maka semakin besar persentase kepemilikan jaminan sosialnya. Persentase kepemilikan jaminan social terendah berada di kabupaten Wonogiri $(41,81 \%)$.

3. Persentase Penduduk yang Merokok Tembakau Selama SebulanTerakhir Antar Kabupaten/Kota di Provinsi Jawa Tengah

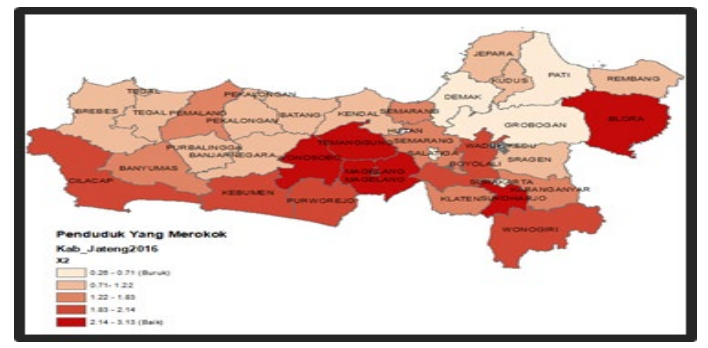

Sumber : Badan Pusat Statistik, publikasi.

Gambar 3. Pola sebaran persentase penduduk merokok di Jawa Tengah tahun 2017

Gambar 3 memvisualisasikan persentase penduduk yang merokok pada masing-masing kabupaten/kota di Jawa Tengah pada tahun 2017. Pengelompokan kelas interval dilakukan dengan menggunakan natural breaks Jenk (meminumkan varians dalam kelas dan memaksimalkan varians antar kelas). Warna muda menunjukan kabupaten/kota dengan nilai persentase penduduk yang merokok sebesar $0,26 \%-0,71 \%$. Sedangkan warna merah tua menunjukan kabupaten/kota dengan nilai persentase penduduk yang merokok 2,14\% $3,13 \%$. Semakin gelap warna suatu kabupaten/kota maka semakin besar persentase penduduk yang merokok. Persentase penduduk yang merokok terendah berada di Kabupaten Surakarta $(0,26 \%)$.

4. Persentase Penduduk Miskin Antar Kabupaten/Kota di Provinsi Jawa Tengah

Persentase penduduk miskin pada masing-masing Kabupaten/Kota di Jawa Tengah pada tahun 2017. Pengelompokan interval kelas pada persentase penduduk miskin didasarkan dari pengkategorian tingkat kemiskinan oleh lembaga Penelitian SMERU. Secara Umum, tingkat penduduk miskin di kabupaten/kota termasuk dalam kategori menengah bawah, yakni $10 \%$ - 15\%. Warnah putih menunjukkan kabupaten/kota dengan persentase penduduk miskin yang masuk kategori rendah. Warna hijau tua menunjukkan kabupaten/kota dengan 
persentase penduduk miskin yang termasuk kategori tinggi. Semakin gelap warna suatu kabupaten/kota, maka semakin tinggi persentase penduduk miskin di kabupaten/kota tersebut. Persentase penduduk miskin tertinggi adalah Kabupaten Wonosobo sebesar 20,32\% sedangkan yang terkecil adalah Kota Semarang sebesar $4,62 \%$.

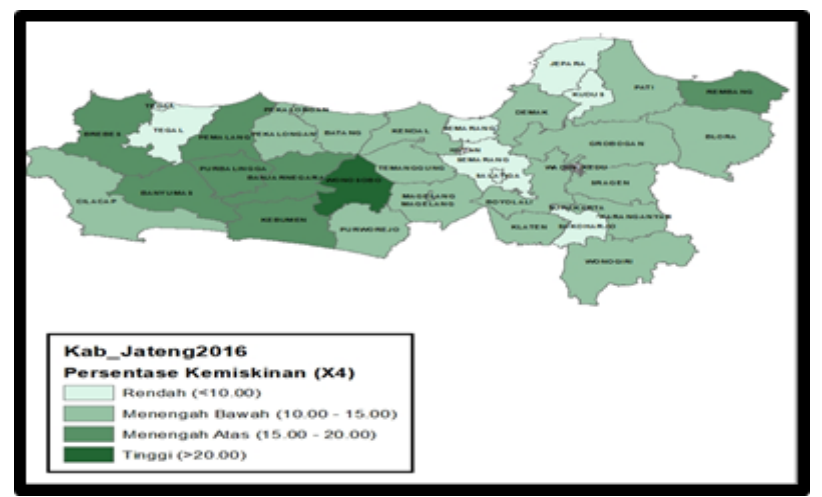

Sumber : Badan Pusat Statistik, publikasi.

Gambar 4. Pola sebaran persentase penduduk miskin di Jawa Tengah tahun 2017

5. Persentase Penduduk yang Memiliki Sanitasi Layak Antar Kabupaten/Kota di Provinsi Jawa Tengah

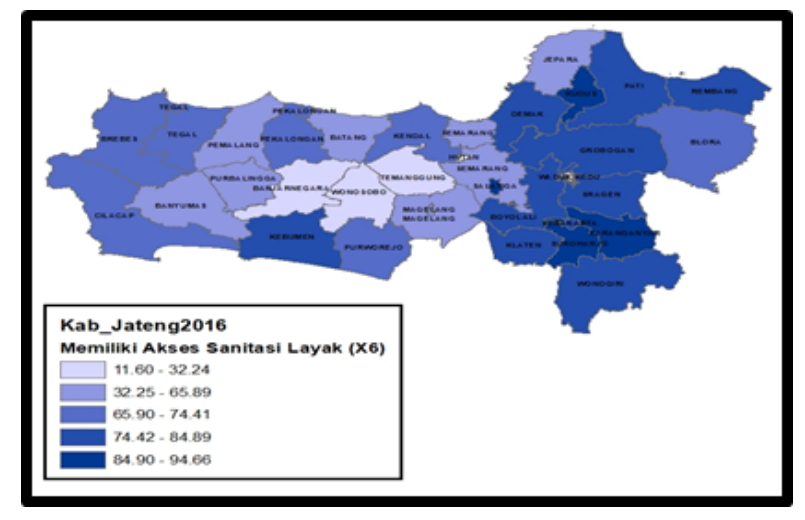

Sumber : Badan Pusat Statistik, publikasi.

Gambar 5. Pola sebaran pesentase rumah tangga yang memiliki akses sanitasi layak di Provinsi Jawa Tengah tahun 2017

Gambar 5 memvisualisasikan persentase rumah tangga yang memiliki akses sanitasi layak pada masing-masing Kabupaten/Kota di Jawa tengah pada tahun 2017. Pengelompokan kelas interval dilakukan dengan menggunakan natural breaks (meminimumkan varians dalam kelas dan memaksimumkan varians antara kelas). Secara umum, rumah tangga yang memiliki akses sanitasi layak Kabupaten/Kota di Jawa Tengah berada di antara 74,42\% - 84,49\%. Warna putih menunjukkan kabupaten/kota dengan persentase rumah tangga yang memiliki akses sanitasi layak paling sedikit yaitu sebesar $11,6 \%-32,24 \%$. Semakin gelap warna suatu kabupaten/kota, maka semakin banyak jumlah rumah rumah tangga yang memiliki akses sanitasi layak. Persentase rumah tangga yang memiliki akses sanitasi layak terbesar berada di Kabupaten Salatiga dengan persentase sebesar 94,66\% sedangkan yang paling sedikit adalah di Kabupaten Purworejo sebesar 11,60\%.

6. Rasio Fasilitas Kesehatan Setiap 30.000 Penduduk Antar Kabupaten/Kota di Provinsi Jawa Tengah

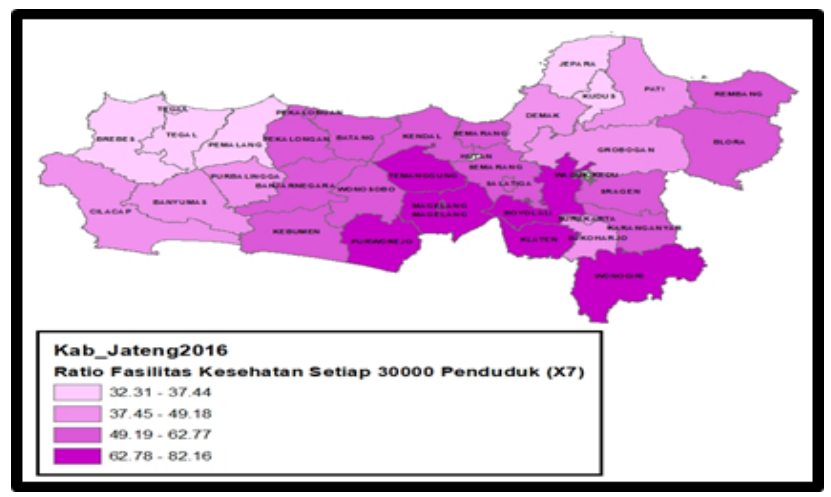

Sumber : Dinas Kesehatan dalam Badan Pusat Statistik, diolah.

Gambar 8. Pola sebaran ratio fasilitas kesehatan terhadap 30.000 penduduk di Jawa Tengah tahun 2017

Gambar 8 memvisualisasikan rasio fasilitas kesehatan terhadap 30.000 penduduk pada masing-masing kabupaten/kota di Jawa tengah pada tahun 2017. Pengelompokan kelas interval dilakukan dengan menggunakan natural breaks (meminimumkan varians dalam kelas dan memaksimumkan varians antara kelas). Secara umum, rasio Kabupaten/Kota di Jawa Tengah berada di antara 49 sampai 62 . Artinya, terdapat fasilitas kesehatan antara 49 sampai 62 di Kabupaten/Kota setiap 30.000 penduduk. Warna ungu muda menunjukkan kabupaten/kota dengan nilai rasio fasilitas kesehatan sebesar 32,31 sampai 37,44. Semakin gelap warna suatu 
kabupaten/kota, maka semakin besar rasio fasilitas kesehatan terhadap 30.000 penduduk di kabupaten/kota tersebut. Ratio fasilitas kesehatan terbesar berada di Kabupaten Purworejo dengan rasio 82,16 per 30.000 penduduk sedangkan rasio terkecil adalah di Kabupaten Pemalang sebesar 32,31 per 30.000 penduduk.

\section{Analisis Inferensia}

1. Regresi Linier Berganda

\section{a. Multikolinieritas}

Tabel 4.1 Uji Multikolinearitas

\begin{tabular}{c|c|c|c|c|c}
\hline ar & 1 & 2 & 3 & 4 & 5 \\
\hline IF &, 279 &, 287 &, 336 &, 284 &, 312 \\
\hline
\end{tabular}

Untuk memeriksa multikoliniearitas antar variable prediktor menggunakan nilai VIF ditampilkan pada Tabel diatas. Hasil VIF menunjukkan VIF masing-masing kurang dari 10, maka dapat dikatakan bahwa tidak ada multikolinearitas antar variable prediktor.

\section{b. Heteroskedastisitas}

Berdasarkan Uji Breusch Pagan test menunjukkan bahawa nilai probabilitynya adalah 0.33299 . Artinya nilai probability lebih besar dari nilai alpha 0.11 yang artinya gagal tolak $\mathrm{H}_{0}$, yaitu tidak terdapat heteroskedastistisitas pada data.

\section{c. Autokorelasi}

Berdasarkan Uji Durbin-Watson nilai probability yang dihasilkan yaitu 0,1511 . Dimana nilai Probability nya lebih besar dari $\alpha=$ $11 \%$ yang artinya gagal tolak $\mathrm{H}_{0}$, yaitu tidak terdapat autokorelasi atau non-autokorelasi pada data.

\section{d. Uji Normalitas}

Tabel 4.3 Hasil Pengolahan Data Dependensi Spasial Morbiditas

\begin{tabular}{l|l|l|l|l}
\hline No & Uji Spasial Dependensi & Nilai & p-value & Kesimpulan \\
\hline 1 & Moran's Index & 1,6170 & 0,10587 & Tolak $\mathrm{H}_{0}$ \\
\hline 2 & Lagrange Multiplier -lag & 3,1722 & 0,07490 & Tolak $\mathrm{H}_{0}$ \\
\hline 3 & Lagrange Multiplier -error & 0,5902 & 0,44233 & Gagal Tolak $\mathrm{H}_{0}$ \\
\hline 4 & Roobust Lagrange Multiplier - lag & 5,6808 & 0,01715 & Tolak $\mathrm{H}_{0}$ \\
\hline 5 & Roobust Lagrange Multiplier - error & 3,0988 & 0,07835 & Tolak $\mathrm{H}_{0}$ \\
\hline 6 & Lagrange Multiplier - SARMA & 6,2710 & 0,04348 & Tolak $\mathrm{H}_{0}$ \\
\hline
\end{tabular}

Berdasarkan Uji Shapiro-wilk nilai probability yang dihasilkan adalah 0,2606. Dimana nilai probability nya lebih besar dari $\alpha=$ $11 \%$ yang artinya gagal tolak $\mathrm{H}_{0}$, yaitu residual data berdistribusi normal.

Tabel 4. 2 Hasil Uji Shapiro Wilk

\begin{tabular}{c|c|c|c}
\hline Var & Koef & $\boldsymbol{P}$-value & Ket \\
\hline Intercept & 3,61907 & 0,00298 & Signifikan \\
\hline $\mathrm{X}_{1}$ & 0,205963 & 0,19862 & $\begin{array}{c}\text { Tidak } \\
\text { signifikan }\end{array}$ \\
\hline $\mathrm{X}_{2}$ & 0,0883594 & 0,20459 & $\begin{array}{c}\text { Tidak } \\
\text { signifikan }\end{array}$ \\
\hline $\mathrm{X}_{3}$ & 0,212799 & 0,06669 & Signifikan \\
\hline $\mathrm{X}_{4}$ & $-0,142002$ & 0,14293 & $\begin{array}{c}\text { Tidak } \\
\text { signifikan }\end{array}$ \\
\hline $\mathrm{X}_{5}$ & $-0,434823$ & 0,00883 & Signifikan \\
\hline
\end{tabular}

2. Model Regresi OLS

$$
\widehat{y}_{\imath}=3,61907+0,212799 X_{3 i}-0,434823 X_{5 i}
$$

Dari model yang telah dihasilkan didapat kan bahwa variabel independen yang signifikan d i dalam model adalah variabel $\mathrm{X}_{3}$ dan $\mathrm{X}_{5}$.

\section{Autokorelasi Spasial}

Setelah semua asumsi OLS terpenuhi seperti homoskedastisitas, normal dan non multikolineartas. Selanjutnya diagnosis ini untuk mengetahui apakah ada efek spasial, dilakukan pengujian asumsi autokorelasi spasial dengan statistik uji Global Moran's Index. Pada dependen angka morbiditas. penimbang yang digunakan adalah Queen contiguity dengan memasukkan order contiguity sebesar 1 yang memiliki arti bahwa suatu kabupaten atau kota akan memiliki tetangga sampai 3 sampai 4 layer berdasarkan persinggungan sisi dan titik antara daerah satu dengan lainnya.

Uji Moran's Index bertujuan untuk mengidentifikasikan apakah ada dependesi/keterkaitan spasial antar wilayah dengan hipotesis yang dikemukakan adalah ; 
Berdasarkan tabel diatas diperoleh nilai p-value morbiditas dari Moran's Indeks sebesar 0.10587 yang berarti tolak $\mathrm{H}_{0}$ atau dengan signifikan $11 \%$ terdapat dependensi spasial morbiditas secara global antar wilayah kabupaten atau kota di Jawa Tengah.

\section{Pemilihan Model Spasial}

Uji Lagrange Multiplier-Lag bertujuan untuk mengidentifikasi adanya keterkaitan antar wilayah. Hasil pengolahan diperoleh nilai $p$ value LM-lag pada morbiditas 0,07490 kurang dari $\alpha=0,11$ atau tolak $\mathrm{H}_{0}$, yang berarti dengan tingkat kepercayaan $89 \%$ dimana terdapat dependesi spasial lag antar wilayah. Selanjutnya Uji Lagrange Multiplier-Error bisa mendiagnosis fenomena dependensi/keterkaitan error antar wilayah. Hipotesis yang diajukan :

Hasil pengolahan diperoleh nilai p-value LM-error pada morbiditas 0,4423 lebih besar dari $\alpha=0,11$ atau gagal tolak $\mathrm{H}_{0}$, yang berarti dengan tingkat kepercayaan $89 \%$ dimana tidak terdapat dependesi spasial error antar wilayah.

Model spasial berdasarkan uji Lagrange Multiplier dimana tidak dilanjutkan uji Robust Lagrange Multiplier karena sudah signifikan pada LM-lag, yang mana mendeteksi adanya dependensi spasial secara lebih spesifik yaitu dependensi spasial dalam hal lag dan error. Terdapat dependensi spasial pada lag dan tidak terdapat dependensi spasial pada error sehingga perlu dilanjutkan ke pemodelan model spasial autoregressive model (SAR).

Tabel 4.4 Estimasi Parameter SAR Morbiditas

\begin{tabular}{c|c|c|c}
\hline Var & Koef & P-value & Ket \\
\hline Weight & 0,349561 & 0,04525 & Sig \\
\hline Constan & 2,11187 & 0,05606 & Sig \\
\hline $\mathrm{X}_{1}$ & 0,187354 & 0,16239 & Tidak sig \\
\hline $\mathrm{X}_{2}$ & 0,070911 & 0,22472 & Tidak sig \\
\hline $\mathrm{X}_{3}$ & 0,215482 & 0,02732 & Sig \\
\hline $\mathrm{X}_{4}$ & $-0,10021$ & 0,21525 & Tidak sig \\
\hline $\mathrm{X}_{5}$ & $-0,32082$ & 0,01879 & Sig \\
\hline
\end{tabular}

Ket $\mathrm{R}^{2}=0,4354 ; \alpha=11 \%$

Berdasarkan tabel diatas dapat dilihat bahwa nilai $\mathrm{R}^{2}=43,54 \%$ yang berarti model tersebut dapat menjelaskan variasi dari variabel morbiditas $43,54 \%$ dan sisanya sebesar $56,46 \%$ dijelaskan oleh variabel lain di luar model. $P$ value yang signifikan terdapat pada variabel $\mathrm{X}_{3}$ (penduduk miskin) dan $\mathrm{X}_{5}$ (rasio fasilitas kesehatan setiap 30000 penduduk). Berikut persamaan SAR yang diperoleh:

$$
\hat{y}_{i}=2,11187 \sum_{j=1 ; i \neq j}^{n} 0,349 W_{i j} y_{j}+0,215 X_{3 i}-0,321 X_{5 i}
$$

Koefisien rho $(\rho)$ secara signifikan menunjukan suatu wilayah yang dikelilingi wilayah lainnya sebanyak n, maka pengaruh dari masing wilayah terhadap wilayah tersebut sebesar 0,34956 dikali rata-rata variabel dependen di sekitarnya. Koefisien variabel persentase penduduk miskin $\left(\mathrm{X}_{3}\right)$ postif atau setiap kenaikan satu unit akan meningkatkan nilai morbiditas di Jawa Tengah sebesar 0,21548 dengan asumsi variabel lain konstan. Sedangkan rasio fasilitas kesehatan setiap 30.000 penduduk $\left(\mathrm{X}_{5}\right)$ berpengaruh negatif atau setiap kenaikan satu unit akan menurunkan nilai Morbiditas di Jawa Tengah sebesar 0,32082 dengan asumsi variabel lain konstan.

Model tersebut selanjutnya melalui uji heteroskedastisitas dengan uji Breusch-Pagan. Hasil pengolahan diperoleh nilai $p$-value Breusch-Pagan 0,4423 lebih besar dari $\alpha=11 \%$ atau gagal tolak $\mathrm{H}_{0}$, yang berarti dengan tingkat kepercayaan $89 \%$ di mana persamaan dengan model SAR tidak memenuhi asumsi heteroskedastis, dengan kata lain model SAR memenuhi asumsi homoskedastisitas.

\section{Pemilihan Model Terbaik}

Pemilihan model terbaik dilakukan dengan membandingkan $\mathrm{R}^{2}$, nilai AIC dan uji likelihood. Pada tabel Nilai $\mathrm{R}^{2}$ dan AIC RLB dan SAR, diperoleh $\mathrm{R}^{2}$ dari model SAR lebih besar daripada model RLB dan nilai AICnya lebih kecil dari model RLB.

Tabel 4.5 Nilai $\mathrm{R}^{2}$ dan AIC RLB dan SAR

\begin{tabular}{l|l|l}
\hline & RLB & SAR \\
\hline $\mathrm{R}^{2}$ & 0.3618 & 0.4354 \\
\hline AIC & -6.33956 & -7.5659 \\
\hline
\end{tabular}


Pengujian likelihood ratio untuk mengidentifikasikan apakah model SAR lebih baik dibandingkan dengan model regresi linear berganda (RLB).Berdasarkan p-value uji likelihood ratio sebesar 0.07246 lebih kecil dari tingkat signifikansi $11 \%$ hal tersebut menunjukkan bahwa tolak $\mathrm{H}_{0}$ sehingga model spasial autoregressive model SAR lebih baik dibandingkan dengan regresi linier berganda (RLB).

\section{KESIMPULAN}

Berdasarkan hasil analisis pada morbiditas, terdapat dependen spasial atau efek spasial. Selanjutnya dengan uji Lag Multiplier didapatkan hasil bahwa kabupaten/kota di wilayah Jawa Tengah terdapat dependensi dalam lag dan tidak dalam error. Oleh sebab itu, dilakukan pemodelan spasial autoregressive model atau SAR. Kemudian dari model yang terbentuk, diperoleh variabel prediktor yang signifikan memengaruhi variabel respon (morbiditas) secara spasial pada alpha $11 \%$, yaitu variabel kemiskinan atau $\mathrm{X}_{3}$ dan variabel rasio fasilitas kesehatan per 30000 penduduk atau $\mathrm{X}_{5}$ dengan nilai $\mathrm{R}^{2} 46 \%$ dan model terbaik untuk analisis spasial ini adalah model spasial autoregressive model SAR.

\section{DAFTAR PUSTAKA}

[1] Arifianto, Eko. (2010). Mengukur Kinerja Kota-kota di Indonesia dengan Pendekatan City Development Index (CDI) Kajian Studi pada 32 Kota di Pulau Jawa Tahun 2008 [Tesis]. Program Magister Perencanaan dan Kebijakan Publik Jakarta. Fakultas Ekonomi. Universitas Indonesia: Jakarta.

[2] Badan Pusat Statistik Jawa Timur. 2014. Hasil Survei Sosial Ekonomi Nasional Tahun 2014 Provinsi Jawa Timur. Badan Pusat Statistik: Jawa Timur.

[3] Badan Pusat Statistik Jawa Tengah. 2017. Profil Kesehatan Provinsi Jawa Tengah Tahun 2017. Badan Pusat Statistik: Jawa Tengah.

[4] Hanum, D, Purhadi (2013). Faktor-faktor yang Mempengaruhi Morbiditas Penduduk Jawa Timur dengan Multivariate
Geographically Weighted Regression (MGWR). Jurnal Seni dan Sains POMITS, Vol. 2 (2), 189-194.

[5] Republika (2019). BPS Sebut Angka Kesakitan Nasional Cenderung Menurun [Internet]. 27 Nov 2019, 23:08 WIB. [diakses 10 Februari 2019]. Tersedia dari: https://www.republika.co.id/berita/nasional /umum/19/11/27/q1mqum409-bps-sebutangka-kesakitan-nasional-cenderungmenurun

[6] Saputeri, E.A. (2019). Analisis Spasial Angka Morbiditas di Kabupaten/Kota Pulau Jawa Tahun 2017 [Skripsi]. Jakarta: Politeknik Statistika STIS.

[7] Sirusa BPS. Angka Kesakitan (Morbiditas) [Internet],__ , [diakses 10Februari 2020]. Tersedia dari:

https://sirusa.bps.go.id/sirusa/index.php/indikator/16

[8] Wulandari, K., Budiantara, I.N., Ratna, M. (2017). Pemodelan Faktor-Faktor yang Mempengaruhi Angka Morbiditas di Jawa Timur Menggunakan Regresi Nonparametrik Spline. Jurnal Sains dan Seni ITS, Vol. 6 (1), 115-121.

[9]Wuryandari,T.,Hoyi,A.,Kusumawardani,D.S, \&Rahmawati,D.(2014). Identifikasi Autokorelasi Spasial pada Jumlah Pengangguran di Jawa Tengah Menggunakan Indeks Moran. Jurnal Nasional Media Statistika Universitas Diponegoro, Vol. 7(1).

[10]Rahmawati,R.,Safitri,D.,\&Fairuzdhiya,O.U. (2015). Analisis Spasial Pengaruh Tingkat Pengangguran Terhadap Kemiskinan di Indonesia (Studi Kasus Provinsi Jawa Tengah). Media Statistika, Vol. 8 N0. 1, Juni $2015: 23: 30$

[11]Ilahi,R., Syamsuddin,M., \& Suparman,Y.(2013). Model Spasial Durbin Dengan Efek Tetap Untuk Tingkat Pengangguran Terbuka di Provinsi Kepulauan Bangka Belitung. Jurnal Putaka Universitas Padjajaran.

[12]Sari,D.M.,Kusrini,D.E.,\&Suhartono.

(2013).Pemodelan Kasus Tindak Pidana di Kota Surabaya dengan Pendekatan Regresi Spasial.Junal Sains dan Seni POMITS Vol.2, No.2. 